\title{
Polyplacophora from the Eocene of Gánt, Hungary
}

\author{
Bruno Dell'Angelo, Maurizio Sosso, Andreas KroH \& Alfréd Dulal
}

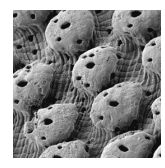

\begin{abstract}
The only species of Polyplacophora known from the Eocene of Gánt is Tonicia pannonica. Re-examination of the type material of this species indicates that the two syntypes of Szôts belong to two different species. One of those syntypes (the tail valve) is designated as lectotype herein, in order to provide stability to nomenclature by preserving the generic attribution of the species pannonica to the genus Tonicia. New samples were collected near the type locality, and the nearly 200 valves recovered belong to four species: Tonicia pannonica, Lepidochitona gantensis sp. nov., L. szoetsi sp. nov., and L. viciani sp. nov. The paralectotype of Tonicia pannonica, an intermediate valve, is here excluded from that species and attributed to Lepidochitona szoetsi sp. nov. $•$ Key words: Mollusca, Polyplacophora, systematics, Eocene, Hungary, Gánt.
\end{abstract}

Dell'Angelo, B., Sosso, M., KROH, A. \& Dulai, A. 2015. Polyplacophora from the Eocene of Gánt, Hungary. Bulletin of Geosciences 90(2), 359-370 (8 figures, 1 table). Czech Geological Survey, Prague. ISSN 1214-1119. Manuscript received April 25, 2014; accepted in revised form December 11, 2014; published online February 4, 2015; issued March 23, 2015.

Bruno Dell'Angelo, Museo di Zoologia, Via Selmi 3, 40126 Bologna, Italy; bruno.dellangelo@chitons.it • Maurizio Sosso, Via Bengasi 4, 16153 Genova, Italy; sosmauri@gmail.com• Andreas Kroh (corresponding author), Natural History Museum Vienna, Burgring 7, 1010 Wien, Austria; andreas.kroh@nhm-wien.ac.at • Alfréd Dulai, Hungarian Natural History Museum, Department of Palaeontology and Geology, P.O.B. 137, 1431 Budapest, Hungary; dulai@nhmus.hu

In comparison to their Neogene record Palaeogene chitons (Mollusca: Polyplacophora) are poorly known. Only 79 Palaeogene species were reported in a comprehensive review by Dell'Angelo et al. (2011). Since then Cabrera \& Olivero (2011) and Dell'Angelo et al. (2012) each described rare unnamed chiton species from the Eocene of Antarctica and Italy respectively. The large majority of Palaeogene chiton records are from the Eocene of Europe, particularly from Germany, France, the United Kingdom and the Ukraine (reflecting centres of mollusc research rather than chiton palaeobiodiversity hotspots). Oligocene records even are less prevalent, followed by very scare Paleocene examples (Dell'Angelo et al. 2011, Appendix 2). Non-European chitons from Palaeogene strata are restricted to few scattered records from the United States, Australia and New Zealand. Moreover, most Palaeogene chiton species are known from single outcrops only, making biogeographic inference impossible. It is clear, however, that this is due to sampling bias rather than to true absence in the fossil record, as exemplified by the study of Dell'Angelo et al. (2011) and the present one. Chiton remains are often overlooked by collectors and researchers (Puchalsky et $a l$. 2008) due to their resemblance to fragments of other molluscs and, often, small size.
Similarly to the global situation, chitons from the Hungarian Palaeogene Basin are poorly documented, too. The only reports are Tonicia pannonica Szôts, 1953 from the Eocene of Gánt and Neszmély (Sző́ts 1953, Strausz 1974), and Chiton bernayi Cossmann, 1888 from the Eocene of Mány (Kecskeméti-Körmendy 1990), which is based on a single head valve that until now could not be located in the collections of the Hungarian Geological and Geophysical Institute (Budapest, Hungary).

The original description of $T$. pannonica is based on two valves, a tail valve and an intermediate valve. Re-examination of the type material (deposited in the Hungarian Geological and Geophysical Institute; inventory number: E.1.) revealed that these two valves are not conspecific, but instead belong to two different species of different generic affinity. Consequently the description and diagnosis of Tonicia pannonica needs to be emended. New material collected from the same stratigraphic level near the type locality includes a large number of chiton valves. Based on these new specimens it is possible, for the first time, to characterize the morphology of the head and intermediate valves of this species. In addition, the material revealed the presence of three additional chiton species in Gánt and offers new insights on the chiton fauna from the Eocene of Hungary. 


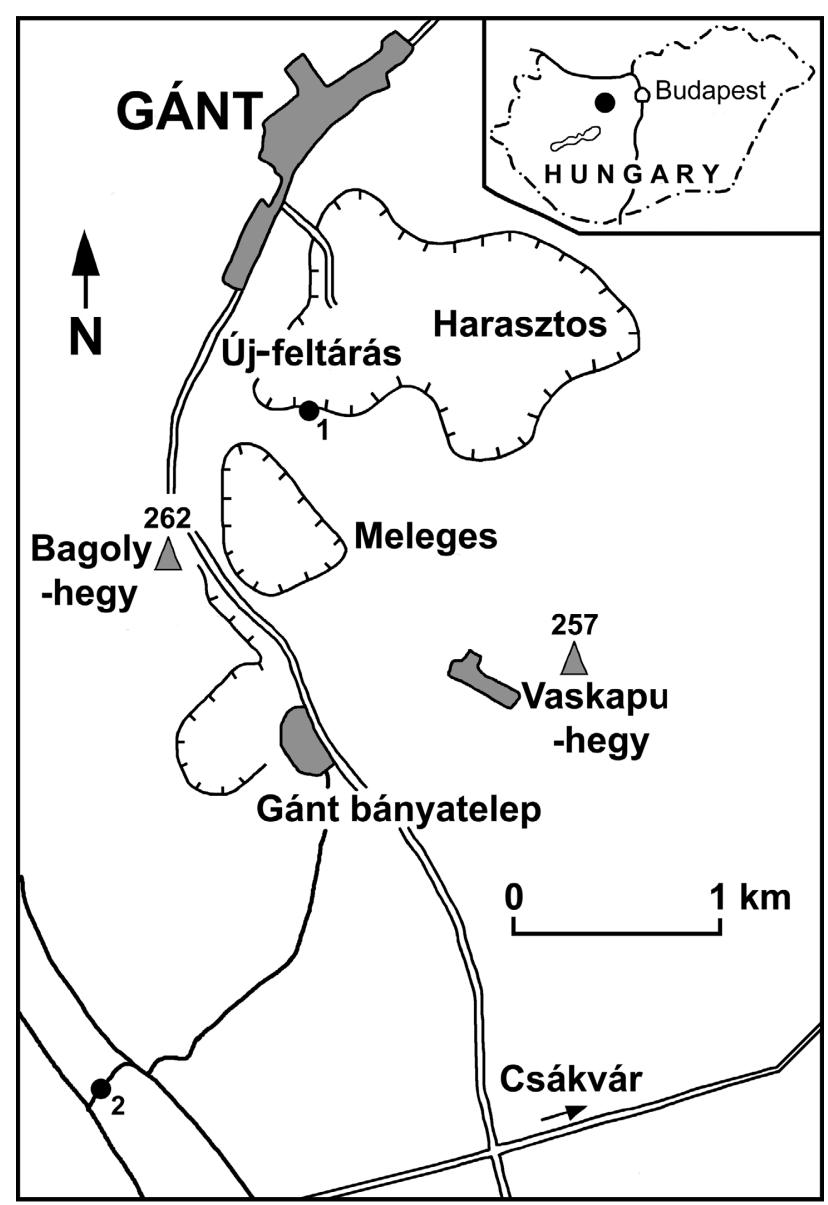

Figure 1. Location map. 1 -Szôts's locality (Új-feltárás = new exposure in Szóts 1953); 2 - Vicián's locality at the vineries around Gánt (2010-2013).

\section{Methods}

The present work is based mainly on bulk samples collected by a friend of the authors (Zoltán Vicián, Budapest) between 2010 and 2013. The sediment has been processed by wet-sieving (sieve mesh width $0.5,1.0$, and $2.0 \mathrm{~mm}$ ). Chiton valves were picked from the $0.5,1.0$ and $2.0 \mathrm{~mm}$ fractions using a stereomicroscope. Additional specimens were donated by Helmut Krock (Lüneburg, Germany). SEM-work was carried out at the Natural History $\mathrm{Mu}$ seum Vienna using the JEOL 6400 and 6610LV scanning electron microscopes of the Central Research Laboratories.

\section{Geological setting}

The Vértes Hills belong to the NE part of the Transdanubian Range in Hungary. The mass of the Vértes comprises Middle and Upper Triassic dolomite and limestone overlain by Jurassic, Lower Cretaceous, Eocene and Upper
Miocene formations with smaller spatial extent and thickness (Budai et al. 2008). The SW-NE oriented Gánt Depression is situated inside the Vértes Hills and is part of the Hungarian Palaeogene Basin. The Eocene deposits at Gánt are best exposed in an abandoned open-cast bauxite mine (Fig. 1), where transgressive neritic sediments overly the terrestrial bauxite deposits. The lowermost part of the section is built up of lacustrine and terrestrial deposits overlain by oscillatory succession, which were deposited in a variably restricted brackish-water or marine lagoonal environment (late Lutetian-early Bartonian Forna Formation; Budai et al. 2008). The overlying Kincses Formation with very variable lithology accumulated in a shallow-marine lagoon, most probably in the Bartonian. Its lower part contains the so-called "brown molluscan clay", which crops out also at vineries around Gánt (Szôts 1953, Budai et al. 2008). These beds are highly fossiliferous and have yielded the rich mollusc fauna monographed by Szôts (1953). Among the other fossil groups the abundant ostracods (Monostori 1977), the charophytes and palynomorphs (Bignot et al. 1985), the foraminifers (Halupka 1999) and the fishes (Nolf \& Reichenbacher 1999) were studied in detail. The palaeoecological characters of the locality were discussed by Strausz (1962), Mihály (1975) and Mihály \& Vincze (1984) (mainly on the basis of the mollusc fauna). Based on the large benthic foraminifers, molluscs, palynomorphs and ostracods this section was attributed to the Middle Eocene. In absence of planktonic fossils, a more precise age is impossible to identify, however, on the basis of lithological analogies with NE Bakony and SW Vértes sections and boreholes, the most probable age of this series is late Lutetian to early Bartonian (Kollányi et al. 2003, Budai et al. 2008). A detailed description of the Gánt section can be found in Bignot et al. (1985, fig. 2). Szóts (1953) outcrop (Loc. 1 in Fig. 1; $47^{\circ} 22.56^{\prime} \mathrm{N}, 18^{\circ} 23.18^{\prime} \mathrm{E}$ ), is inaccessible today, but new samples could be collected from coeval strata to the south of the bauxite mines (Loc. 2 in Fig. $1 ; 47^{\circ} 20.80^{\prime} \mathrm{N}, 18^{\circ} 22.60^{\prime} \mathrm{E}$ ).

Abbreviations. - BD - B. Dell' Angelo Collection, Genova, Italy (will be deposited in MZB); HNHM - Hungarian Natural History Museum, Budapest, Hungary; HGGI - Hungarian Geological and Geophysical Institute, Budapest, Hungary; MNHN - Muséum national d'Histoire naturelle, Paris, France; MZB - Zoological Museum of Bologna University, Bologna, Italy; NHMW - Natural History Museum Wien, Austria; ZISP - Zoological Institute of the Russian Academy of Sciences, St. Petersburg, Russia.

\section{Systematic palaeontology}

We follow the systematic classification proposed by $\mathrm{Si}$ renko (2006). 


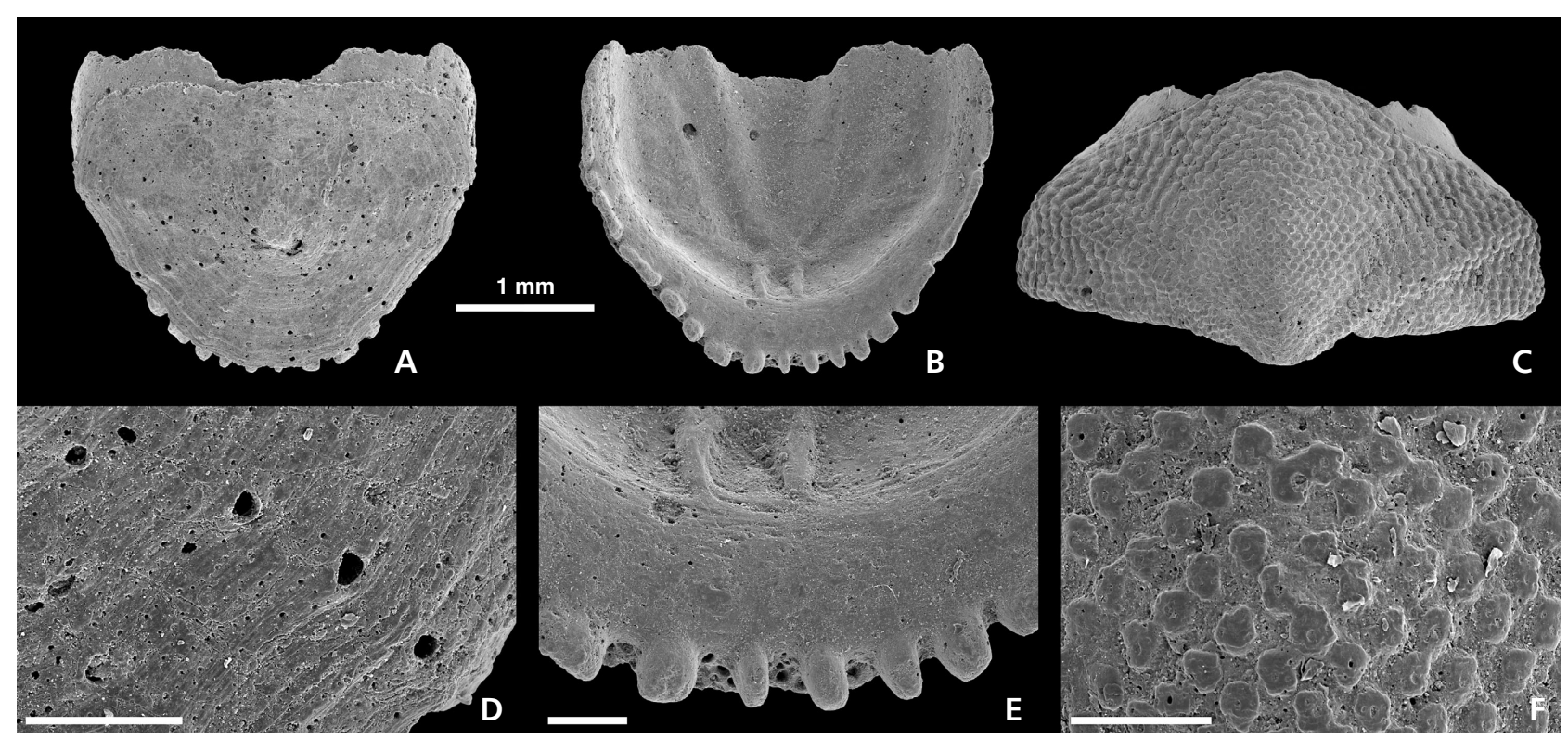

Figure 2. Type material of Tonicia pannonica Szőts, 1953 from the Middle Eocene Kincses Formation of Gánt, Hungary. • A, B, D, E - lectotype (tail valve, HGGI E.1a; A - dorsal view, B - ventral view; D - detail of ocelli pores; E - detail of marginal teeth); C, F - paralectotype (intermediate valve, HGGI E.1b; C - dorsal view; F - detail of median area sculpture), here excluded from T. pannonica and identified as Lepidochitona szoetsi sp. nov. (holotype). Scale bars for D-F equal $200 \mu \mathrm{m}$.

Class Polyplacophora Gray, 1821

Subclass Loricata Shumacher, 1817

Order Chitonida Thiele, 1909

Suborder Chitonina Thiele, 1909

Family Chitonidae Rafinesque, 1815

Subfamily Toniciinae Pilsbry, 1893

\section{Genus Tonicia Gray, 1847}

The genus is known from the Eocene to the Recent.

\section{Tonicia pannonica Szóts, 1953}

Figures 2A, B, D, E, 3A-J, 4A-F

p.p. 1953 Tonicia pannonica nov. sp.; Szôts, p. 132, pl. 1, figs 3, 4 [not figs 1, 2, = Lepidochitona szoetsi sp. nov., see below].

1974 Tonicia pannonica Szôts. - Strausz, pp. 9-10, 98, text-fig. 3.

1981 Tonicia pannonica Szőts. - Van Belle, p. 55.

2011 Tonicia pannonica Szôts. - Dell'Angelo et al., p. 953.

Type.-Lect oty pe: HGGI, E.1a., a tail valve (Fig. 2A, B, D, E), designated herein. Paralectotype: HGGI, E.1b., an intermediate valve (Fig. 2C, F), excluded from Tonicia pannonica and attributed to Lepidochitona szoetsi sp. nov. herein.

Type locality. - Gánt, Eocene (Fig. 1). Szôts (1953) indicated the "Új-feltárás = new exposure" as the locality of his two chiton valves (Loc. 1 in Fig. 1 ; $47^{\circ} 22.56^{\prime} \mathrm{N}, 18^{\circ} 23.18^{\prime} \mathrm{E}$ ). The new samples collected by Z. Vicián are from the vineries around Gánt (Loc. 2 in Fig. 1; $47^{\circ} 20.80^{\prime} \mathrm{N}, 18^{\circ} 22.60^{\prime} \mathrm{E}$ ), which were also among Szőts's localities. In both sections the fossils are from the same level (brown molluscan clay).

Type horizon. - Middle Eocene (?late Lutetian to early Bartonian) molluscan clay at the lower part of Kincses Formation.

Additional material examined (from Loc. 2 in Fig. 1). HNHM: three valves (one head: INV 2013.316; one intermediate: INV 2013.317; one tail: INV 2013.318.) (Fig. 3H-J); NHMW: three valves [one head: NHMW 2014/0203/0001; one intermediate: NHMW 2013/0311/0001 (Fig. 3D-G), and one tail: NHMW 2014/0203/0002]; ZISP 2203: three valves [one head (Fig. 3A-C), one intermediate, and one tail]; $\mathrm{BD} 101$ : nine valves (small fragments): two head, two intermediate, and five tail.

Original description. - "Une valve postérieure et une valve médiane appartenant très probablement à la même espèce ont été trouvées à Új-feltárás.

Toute les deux valves, concernant leur ornamentation et les autres caractéristiques morphologiques, sont très voisines de l'espèce Ch. defrancei De Rocheb. (Cossm., M.: Cat. Ill. III, p. 15. Pl. I, fig. 9) abondant aux environs de Chaussy; mais elles ne sauraient être identifiées avec celle-cí.

La valve mediane est plus étroite que celle de l'espèce parisienne, son ornamentation est beaucoup plus fine et 


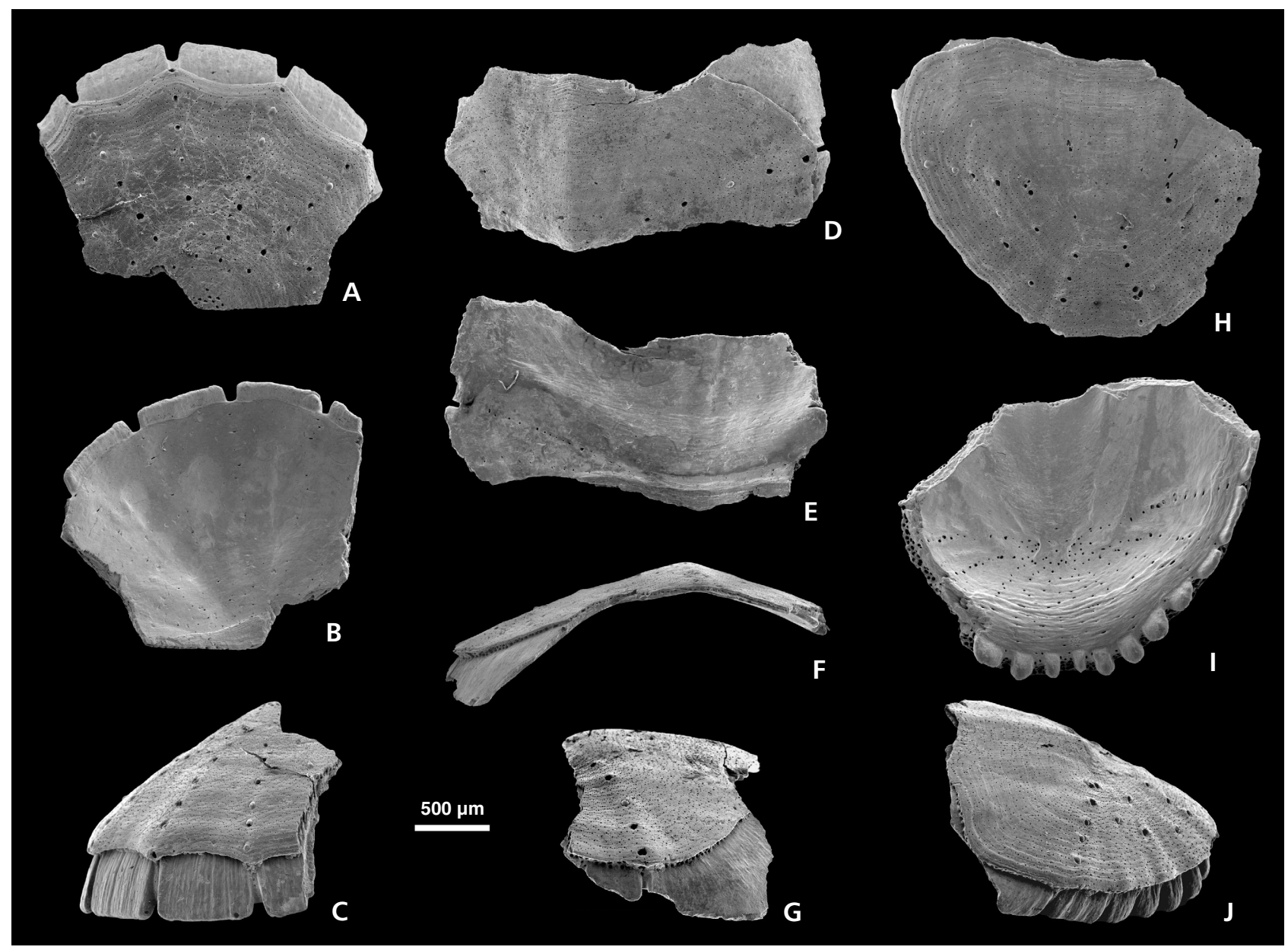

Figure 3. Tonicia pannonica Szőts, 1953 from the Middle Eocene Kincses Formation of Gánt, Hungary. • A-C - head valve (ZISP 2203; A - dorsal view, B - ventral view, C - left lateral view); •D-G - intermediate valve (NHMW 2013/0311/0001; D - dorsal view, E - ventral view, F - anterior view, $\mathrm{G}$ - right lateral view). $\bullet \mathrm{H}-\mathrm{J}$ - tail valve (HNHM INV 2013.318; H - dorsal view, I - ventral view, J - right lateral view).

plus serrée. À son aire latérale, on voit aussi quelques carènes obtuses.

La surface de la valve postérieure est, malhereusement, assez roulée. D'après sa taille, il ressemble quand- même à la Ch. defrancei De Rocheb.

Aux surfaces intérieures de toutes les deux valves, l'on voit bien les places d'adhésion des muscles et les impressions correspondant aux lames d'insertion.

Dimensions: largeur de la valve postérieure: $2,73 \mathrm{~mm}$, largeur de la valve médiane: 3,64 mm." (Szőts 1953, p. 132)

Emended diagnosis. - Tegmentum smooth; radial ridges of ocelli pores on head valve in the contact between central and lateral areas of intermediate valve, and in postmucronal area of tail valves. Tail valve flattened, mucro subcentral, not prominent, anterior and posterior slopes practically straight. Slit formula 7?/1/13, slits deep, teeth strongly grooved on outside and directed outwards in head and tail valves.
Emended description. - Head valve (Fig. 3A-C) incomplete, semicircular, tegmentum smooth with few radial ridges (7?) bearing regular rows of ocelli on the crest (Fig. 4A). Each row comprising six ocelli of oval shape (Fig. 4B, C), with a maximum diameter $c a 55 \mu \mathrm{m}$. Intermediate valve (Fig. 3D-G) incomplete, rectangular, carinated, posterior margin concave at both sides of the less prominent apex, tegmentum smooth, lateral areas separated from the central area by a slight radial ridge with a row of six ocelli of oval shape (maximum diameter ca $52 \mu \mathrm{m}$ ). Tail valve (Fig. 3H-J) elliptical, flattened, front margin straight, mucro subcentral, not prominent, anterior and posterior slopes practically straight, tegmentum smooth, postmucronal area with 13 radial ridges, which bear regular rows of subcircular ocelli (diameter ca $54 \mu \mathrm{m})$.

Tegmentum smooth, densely covered by irregularly arranged macro- and microaesthetes (Fig. 4D).

Articulamentum with rather wide apophyses; slit formula 7?/1/13; slits deep. The teeth are strongly grooved on 

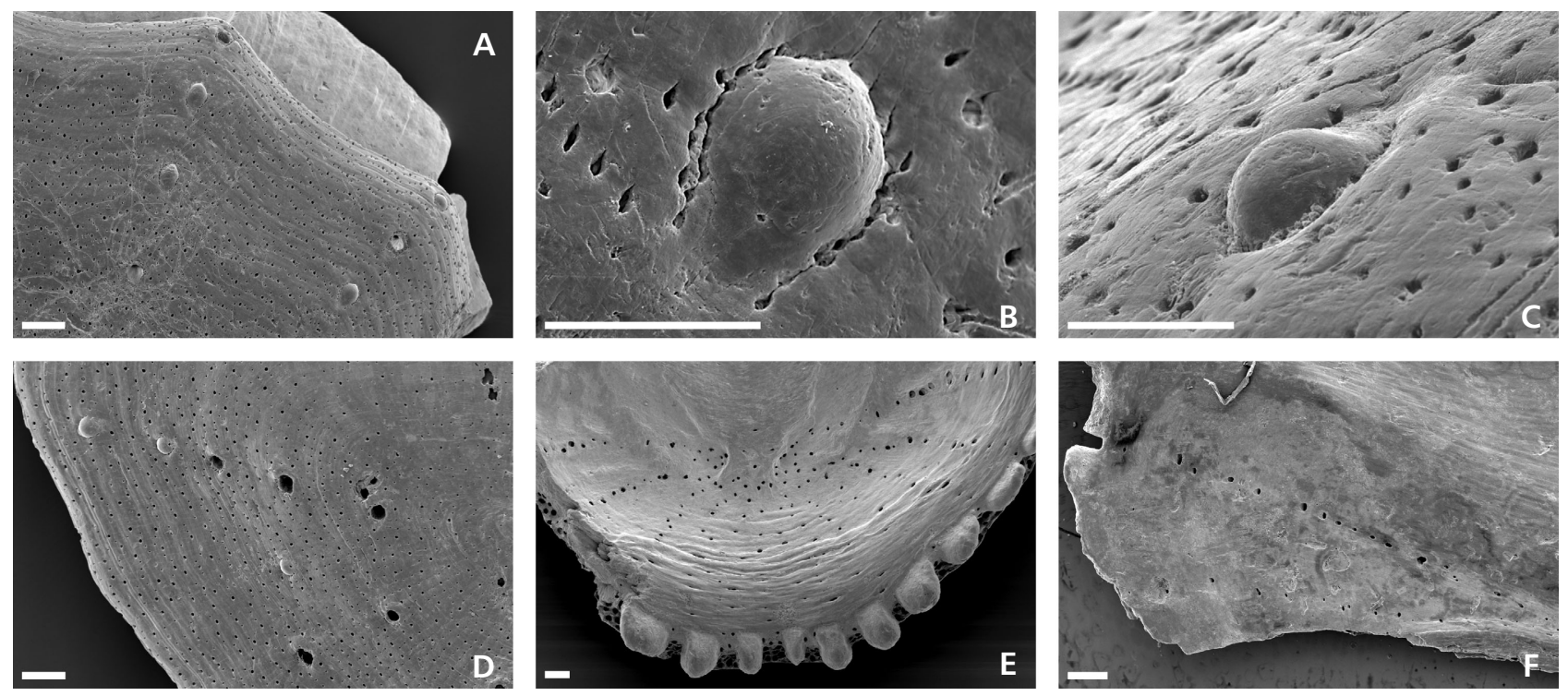

Figure 4. Tonicia pannonica Szőts, 1953 from the Middle Eocene Kincses Formation of Gánt, Hungary. • A-C - head valve (ZISP 2203), close-up of surface ornamentation (A) and ocelli in plan (B) and oblique (C) view; $\bullet$ D, E - tail valve (HNHM INV 2013.318), close-up of surface ornamentation (D) and teeth (E); - F - intermediate valve (NHMW 2013/0311/0001), close-up of internal surface. Scale bars for A and D-F equal $100 \mu \mathrm{m}$, those in B and C equal $50 \mu \mathrm{m}$.

the outside and those of the head and tail valves are directed outwards (Fig. 4E).

Remarks. - Szôts (1953) based his new species Tonicia pannonica on two valves (a tail valve and an intermediate valve), which show radically different ornamentation and in the opinion of the present authors belong to two different species. Szôts did not designate a holotype for T. pannonica. The tail valve is consistent with the morphology of other Tonicia species, characterized by a smooth tegmentum and the presence of ocelli pores (for extra-pigmentary eyes; Kaas et al. 2006). The intermediate valve, in contrast, shows characteristics of the genus Lepidochitona. The tail valve (Szőts 1953, pl. 1, figs 3, 4), therefore, is designated as lectotype herein, in order to provide stability to nomenclature by preserving the generic attribution of the species pannonica to the genus Tonicia.

The ornamentation of the head and intermediate valves found in the newly collected samples from Gánt (Figs 3, 4) is identical with that of the lectotype, and are thus considered to be conspecific here.

Szôts (1953) compared the two valves of his new species with Chiton defrancei de Rochebrune, 1883, a species from the Eocene of the Paris Basin now attributed to the genus Lepidochitona. In that species, the tegmentum is covered by small roundish granules, completely different from the smooth tegmentum of the tail valve designated as lectotype of T. pannonica. Szôts's intermediate valve excluded from T. pannonica here, in contrast shows similarities to $L$. defrancei (see below under Lepidochitona szoetsi sp. nov.).

Some species of chitons known from the Eocene of France (Paris, Cotentin and Loire basins) were attributed to
Tonicia in the past (Dell'Angelo et al. 2011, Appendix 2): T. brasili (Cossmann \& Pissarro, 1902); T. edwardsi de Rochebrune, 1883; T. lennieri (Cossmann \& Pissarro, 1905); T. morgani de Rochebrune, 1883. Unfortunately, the knowledge on the chitons from these basins is poor. Comparison is hampered by the incomplete knowledge on their morphology and lack of SEM documentation. Neither are there any recent revisions of the species reported in the older literature and, the original descriptions are often inadequate. Many of these species thus cannot be attributed with confidence to a specific genus, and are thus considered gen. inquir.

New data (Le Renard \& Gain 2012, p. 84, fig. 81) show that "Chiton" (Tonicia) brasili Cossmann \& Pissarro, 1902 is an elongate chiton, almost vermiform, very different in shape and ornamentation from T. pannonica.

Occurrence. - Tonicia pannonica is known only from the Middle Eocene of Hungary (Gánt: Szőts 1953 and this paper; Neszmély: Strausz 1974).

Suborder Acanthochitonina Bergenhayn, 1930

Family Tonicellidae Simroth, 1894

Genus Lepidochitona Gray, 1821

The genus is known from the Paleocene to the Recent.

Lepidochitona viciani sp. nov.

Figures 5A-L, 6A-F

Type material. - Holotype: NHMW 2013/0311/0006, 


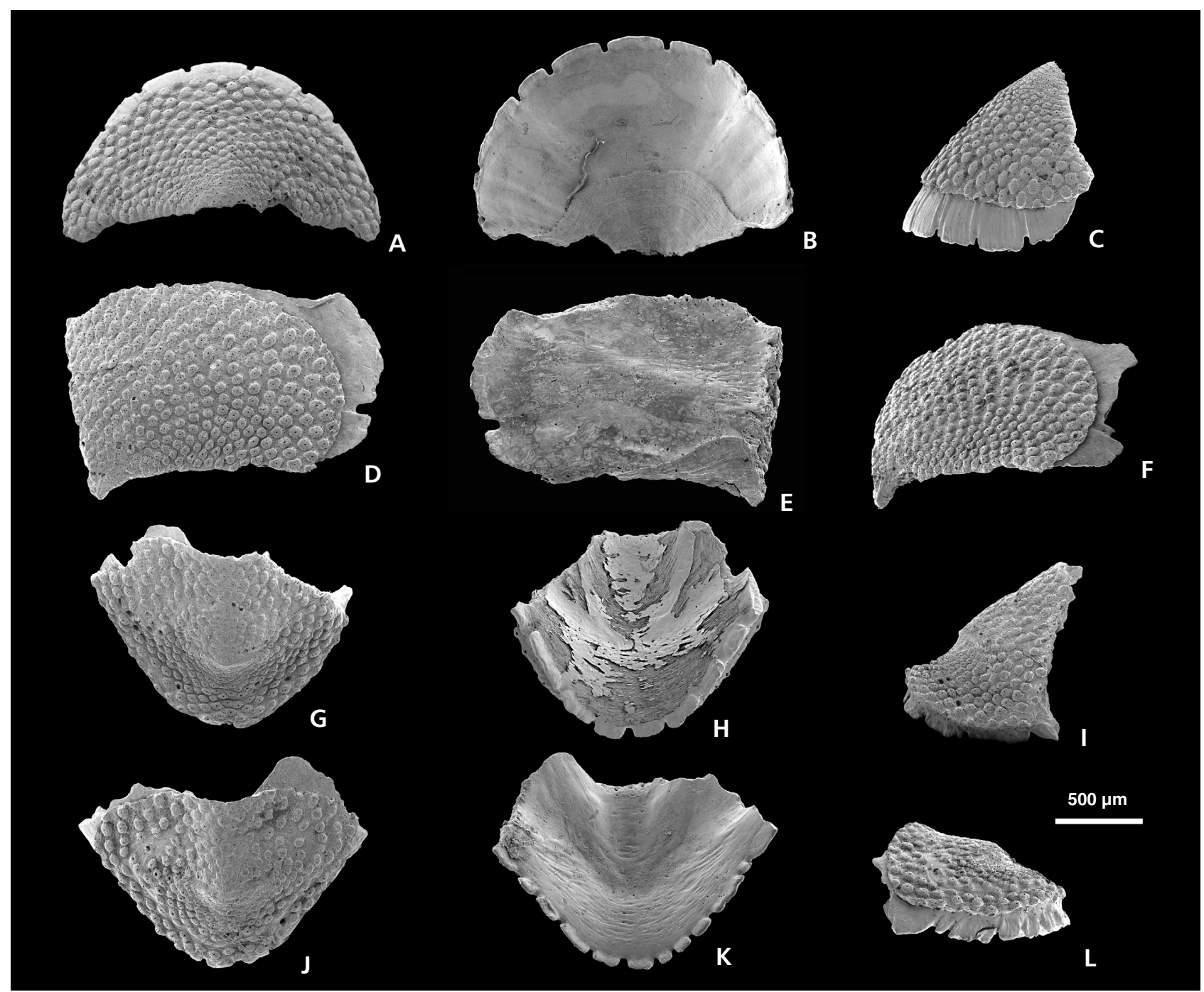

Figure 5. Lepidochitona viciani sp. nov. from the Middle Eocene Kincses Formation of Gánt, Hungary. A-C - head valve (paratype NHMW 2013/0311/0002); D-F - partial intermediate valve (paratype NHMW 2013/0311/0003); G-I: tail valve (paratype HNHM PAL 2013.36.1); J-L: tail valve (holotype NHMW 2013/0311/0006); dorsal (left column), ventral (middle column) and lateral views (right column).

an almost complete tail valve (Fig. 5J-L), width $1.6 \mathrm{~mm}$. Paratypes: HNHM: three valves (one head: PAL 2013.34.1, one intermediate: PAL 2013.35.1, and one tail: PAL 2013.36.1) (Fig. 5G-I); NHMW: three valves (one head: NHMW 2013/0311/0002 (Fig. 5A-C); one intermediate: NHMW 2013/0311/0003 (Fig. 5D-F), and one tail: NHMW 2014/0203/0003); ZISP 2204: three valves (one head, one intermediate, and one tail); BD 102: three valves (one head, one intermediate, and one tail).

Other material. - 11 head, 127 intermediate, and 19 tail valves, most of which are fragmentary (BD coll'n; NHMW 2014/0203/0004, 2014/0203/0005, and 2014/0203/0006).

Type locality. - Gánt, road-cut at the vineries (Hungary) (Loc. 2 in Fig. 1).
Type horizon. - Middle Eocene (?late Lutetian to early Bartonian) molluscan clay in the lower part of the Kincses Formation.

Etymology. - The specific name honours our friend Zoltán Vicián (Budapest, Hungary), who collected the sediment samples from Gánt, and has greatly contributed to the knowledge of the Miocene malacofauna of Hungary.

Diagnosis. - Lateral areas of intermediate valves not distinctly separated from central area; tegmentum ornamented by roundish, elevated, well-separated granules, arranged in an irregular quincunx pattern.

Description. - Head valve (Fig. 5A-C, NHMW 2013/0311/0002) almost semicircular, slope slightly con- 

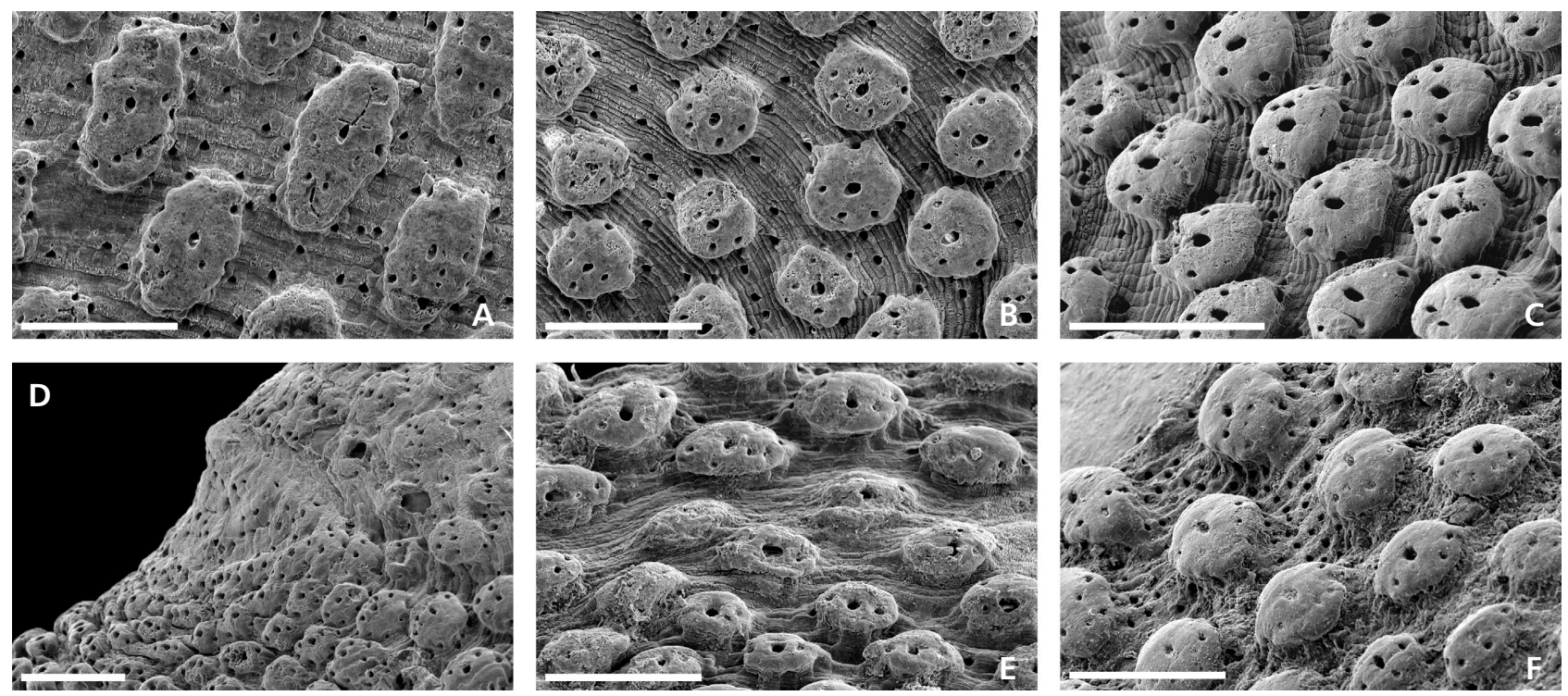

Figure 6. Lepidochitona viciani sp. nov. from the Middle Eocene Kincses Formation of Gánt, Hungary. Close-up of surface ornament. • A-C - intermediate valve (paratype NHMW 2013/0311/0003); D - tail valve (paratype HNHM PAL 2013.36.1); E - tail valve (holotype NHMW 2013/0311/0006); F - head valve (paratype NHMW 2013/0311/0002). Scale bars equal $100 \mu \mathrm{m}$.

vex. Intermediate valve (Fig. 5D-F) rectangular, subcarinated, lateral margins rounded, hind margin concave at both sides of the prominent apex, beaked, lateral areas not distinctly separated from the central area. Tail valve (Fig. 5J-L, NHMW 2013/0311/0006) subtriangular, wider than long, frontal margin sinuate, concave in the jugal part, mucro subcentral, not prominent, anterior slope almost straight or slightly concave, posterior slope concave just behind the mucro (Fig. 6D).

Tegmentum evenly sculptured all over with roundish (Fig. 6A-F), elevated, well-separated granules, arranged in an irregular quincunx pattern. The granules tending to become more irregularly elongate towards the anterior margin of intermediate (Fig. 6A) and tail valves, but always well separated, not coalescing (except in very few cases, e.g. in Fig. 5G, I where two to three coalesced granules can be observed in the antemucronal area of a tail valve). Each granule with a more or less central macroaesthete, and variable number of microaesthetes (three to five, up to seven or eight in more elongate granules) are arranged irregularly along the granule margin. Additional microaesthetes along the bulb of the granule and between granules. Granules roundish, diameter $c a$ 60-65 $\mu \mathrm{m}$ in head valves, $c a$ 55-65 $\mu \mathrm{m}$ in intermediate valves, $c a$ 55-75 $\mu \mathrm{m}$ in tail valves. Elongate granules can reach a maximum length up to $c a 90-110 \mu \mathrm{m}$.

Articulamentum wide, triangular in tail valves, slit formula 8-10/1/8-10, slits deep, teeth strong and very uneven in width, those of the tail valve forwardly directed. Apophyses of intermediate valve not preserved.

Remarks. - This is the most common species found at
Gánt, but almost all valves are broken fragments, of 0.5 to $1.5 \mathrm{~mm}$, mostly half valves. This is a common preservation for thin-shelled polyplacophorans (Sigwart et al. 2014). Some head and tail valves are almost complete, but the intermediate valves are almost always fragmented, and only two or three are more or less complete.

A few chiton species reported from the European Eocene were attributed to Lepidochitona (Dell'Angelo et al. 2011, Appendix 2): L. bernayi (Cossmann, 1888) from France and U.K., L. defrancei (de Rochebrune, 1883) and L. grinionensis (Lamarck, 1802) from France. Those three species are characterized by intermediate valves with a diagonal fold between the lateral and central areas. Such a fold is not present in the material studied here (see discussion below).

Lepidochitona vjalovi Makarenko, 1969, and "Allochiton" menneri (Makarenko, 1969), both from the Paleocene of Ukraine, differ widely from the present specimens, by their tegmentum divided into jugal and pleurolateral areas like species of genus Acanthochitona, the very developed and strongly pectinated insertion plates, and are currently being revised and will possibly be attributed to a separate, new genus (Sirenko, pers. com.).

Lepidochitona oligocaena (Rolle, 1862) from the Oligocene of Gaas (France) differs by the shape of the valves, the densely spaced, quadrangular granules, the presence of two slits in intermediate valves (Kroh \& Dell' Angelo in prep.).

Lepidochitona corrugis (Boettger, 1869) from the Oligocene of Gienberg, near Waldböckelheim (Germany) differs from our species by the coarser sculpture, the elevated lateral areas of the intermediate valves, which are 


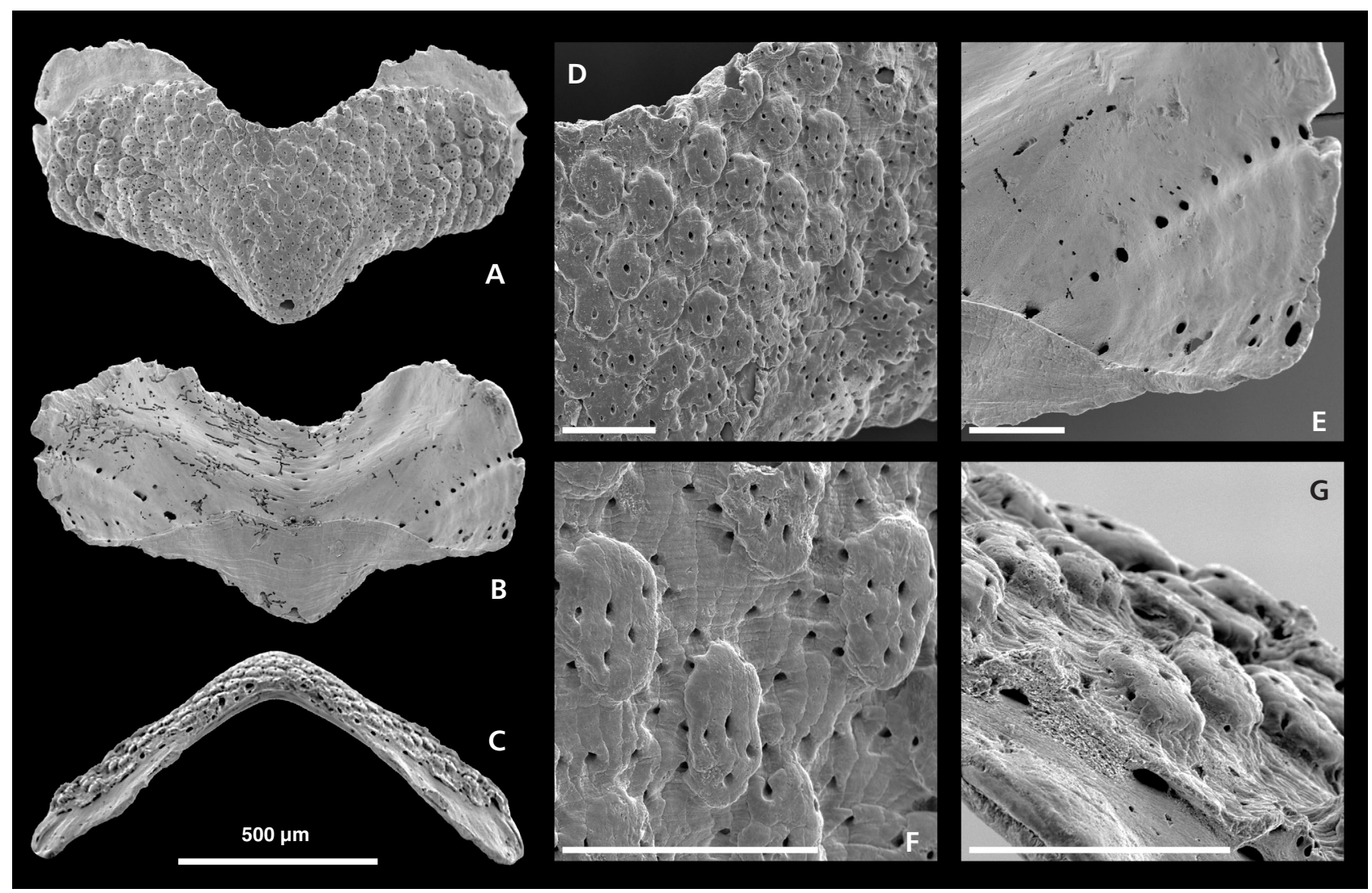

Figure 7. Lepidochitona gantensis sp. nov. from the Middle Eocene Kincses Formation of Gánt, Hungary (holotype, NHMW 2014/0448/0001). - A-G - intermediate valve, dorsal (A), ventral (B) and anterior view (C); close-up of surface ornamentation (D), close-up of internal surface (E), granules in dorsal (F) and oblique view (G). Scale bars D-G equal $100 \mu \mathrm{m}$.

separated from the central areas by a diagonal fold, and by its granules, which are arranged in rows (Janssen 1978).

Occurrence. - Lepidochitona viciani sp. nov. is known only from the Middle Eocene of Gánt (Hungary).

\section{Lepidochitona gantensis sp. nov.}

Figure 7A-G

Type material. - Holoty pe: NHMW: one complete intermediate valve (NHMW 2014/0448/0001, Fig. 7A-C), width $1.2 \mathrm{~mm}$.

Type locality. - Gánt, road-cut at the vineries (Hungary) (Loc. 2 in Fig. 1).

Type horizon. - Middle Eocene (?late Lutetian to early Bartonian) molluscan clay from the lower part of the Kincses Formation.

Etymology. - After the town of Gánt, where the outcrops are situated.
Diagnosis. - Lateral areas of intermediate valves not distinctly separated from central area; tegmentum ornamented by irregular elevated granules arranged in an irregular quincunx pattern; granules well-separated at the valve margin, but coalescing in the jugal area.

Description. - Intermediate valve (Fig. 7A-C) subcarinated, anterior margin with large inward curve in jugal area, lateral margins rounded, hind margin concave at both sides of the prominent and large apex, strongly beaked, lateral areas not distinctly separated from the central area.

Tegmentum evenly sculptured all over with elongate/rectangular (Fig. 7D, F, G), elevated granules, arranged in an irregular quincunx pattern. The granules are not well separated in the jugal area, some of them coalescing, and tending to become more separate towards the lateral margin of the valve. Each granule with a more or less central macroaesthete, and variable number of microaesthetes (three to six) arranged irregularly along the granule margin. Additional microaesthetes along the bulb of the granule and between granules. Granules elongate, length $\mathrm{ca}$ 60-75 $\mu \mathrm{m}$.

Articulamentum wide, apophyses not completely preserved, a single deep slit, teeth strong. 


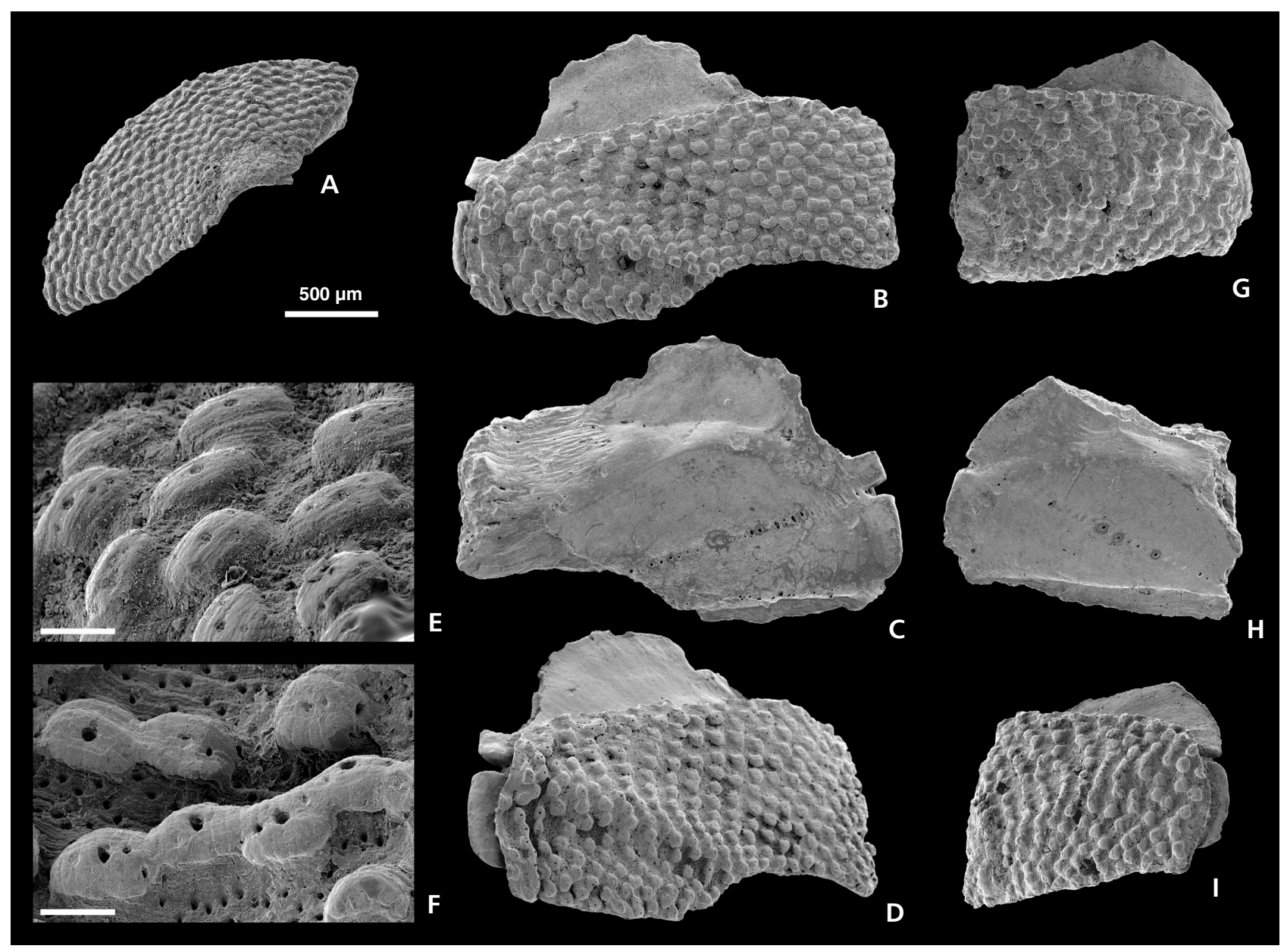

Figure 8. Lepidochitona szoetsi sp. nov. from the Middle Eocene Kincses Formation of Gánt, Hungary. • A - head valve; B-F-intermediate valve (paratype, NHMW 2013/0311/0005), dorsal (B), ventral (C) and oblique lateral view (D); close-up of granules on lateral fold (D) and near lateral margin (F); G-I - intermediate valve (paratype, NHMW 2013/0311/0004), dorsal (G), ventral (H) and oblique lateral view (I). Scale bars E, F equal $50 \mu \mathrm{m}$.

Remarks. - This single intermediate valve is similar to Lepidochitona viciani sp. nov. in having poorly separated lateral areas. It differs from L. viciani, however, by its different shape, with a large apex and strongly beaked form, its less roundish and more quadrangular granules (Fig. 7D, F), which are slightly larger (by ca 10-15\%), more closely spaced and poorly separated. The granules are superficially similar to those of Lepidochitona szoetsisp. nov, but there is no trace of a diagonal fold between the lateral and central areas.

Notwithstanding the scarcity of material, the characters of this species are well defined, and well differentiated from Lepidochitona viciani sp. nov. and L. szoetsi sp. nov., so we describe L. gantensis as a new species here.

Occurrence. - Lepidochitona gantensis sp. nov. is known only from the Middle Eocene of Gánt (Hungary).
Lepidochitona szoetsi sp. nov.

Figure 2C, F, 8A-I

1953 Tonicia pannonica (non Szőts) - Szőts, p. 132, pl. 1, figs 1,2 .

Type material. - Holotype: HGGI, E.1b.: 1 intermediate valve (figured by Szóts 1953, pl. 1, figs 1, 2) (Fig. 2C, 2F). Paratypes (all from Loc. 2 in Fig. 1): NHMW: 1 right half of intermediate valve (NHMW 2013/0311/0004) (Fig. 8G-I), and 1 left half of intermediate valve (NHMW 2013/0311/0005) (Fig. 8B-F); BD 103: 1 incomplete head valve, width $1.7 \mathrm{~mm}$; BD 104: 1 almost complete intermediate valve, width $3.1 \mathrm{~mm}$.

Additional material examined (all from Loc. 2 in Fig. 1). 1 head valve (Fig. 8A) (lost during the SEM study); 3 intermediate incomplete valves, maximum width $2 \mathrm{~mm}$ (BD coll'n). 
Table 1. Main characters of Lepidochitona species from the Eocene of Europe.

\begin{tabular}{|c|c|c|c|c|c|}
\hline & & L. grinionensis & L. defrancei & L. bernayi & L. szoetsi \\
\hline \multirow{3}{*}{ head valve } & sculpture & small granules & larger granules & larger granules & irregular, elevated granules \\
\hline & radial ridges & some radial ridges present & absent & 9 granulated radial ribs & some radial ridges present \\
\hline & slits & 8 & 10 & 9 & $?$ \\
\hline \multirow{6}{*}{$\begin{array}{l}\text { intermediate } \\
\text { valves }\end{array}$} & shape & $\begin{array}{l}\text { rectangular, width twice the } \\
\text { length }\end{array}$ & rectangular, narrow & rectangular, narrow & rectangular \\
\hline & profile & "très arquées" & "très arquées", subcarinated & "peu arquées", rounded & subcarinated \\
\hline & apex & evident & well evident & less evident & less evident \\
\hline & sculpture & $\begin{array}{l}\text { small granules, also more } \\
\text { elongate }\end{array}$ & larger granules & $\begin{array}{l}\text { oblique striae of large } \\
\text { granules }\end{array}$ & $\begin{array}{l}\text { irregular, elevated granules, } \\
\text { some coalescing }\end{array}$ \\
\hline & lateral areas & $\begin{array}{l}\text { narrow, and separated from } \\
\text { central area by a rib }\end{array}$ & $\begin{array}{l}\text { wide and separated from central } \\
\text { area by some ribs }\end{array}$ & $\begin{array}{l}\text { narrow, separated from } \\
\text { central area by a large rib }\end{array}$ & $\begin{array}{l}\text { separated from central area } \\
\text { by a diagonal fold }\end{array}$ \\
\hline & slits & & & & 1 \\
\hline \multirow{4}{*}{ tail valve } & shape & $\begin{array}{l}\text { "scutiforme, autour duquel } \\
\text { rayonnent quatre } \\
\text { dépressions" }\end{array}$ & $\begin{array}{l}\text { "demi-circulaire, marqué de deux } \\
\text { dépressions qui remontent vers le } \\
\text { haut" }\end{array}$ & & \\
\hline & mucro & subcentral, well evident & central, less evident & & \\
\hline & sculpture & small granules & $\begin{array}{l}\text { larger granules, more fine in the } \\
\text { postmucronal area }\end{array}$ & & \\
\hline & slits & & & & \\
\hline
\end{tabular}

Type locality. - Gánt, "new exposure” of Szôts (1953) (Hungary) (Loc. 1 in Fig. 1).

Type horizon. - Middle Eocene (?late Lutetian to early Bartonian) molluscan clay from the lower part of the Kincses Formation.

Etymology. - The specific name honours Endre Szôts, a recognized Hungarian malacologist, who collected the holotype.

Diagnosis. - Head valve with radial ridges; lateral areas of intermediate valves separated from central area by a diagonal fold; tegmentum ornamented by elevated, rectangular granules arranged in a chess-board pattern.

Description. - The head valve bears few radial ridges that correspond to the slits in the insertion lamina. Intermediate valve rectangular, subcarinate, with rounded lateral margins. Hind margin slightly concave at both sides of the apex. Lateral areas distinctly separated from the central area by a diagonal fold.

Tegmentum evenly sculptured all over with irregular polygonal, elevated, poorly separated granules, arranged in an irregular chess-board pattern (Fig. 8E). Those on the head valve are more roundish. Towards the diagonal folds of intermediate valves the granules tend to become coarser, irregularly elongate and coalescing laterally, forming longitudinal rows (Fig. 8F). Each granule bearing a more or less central macroaesthete, and some microaesthetes, which are irregularly arranged along the margin. In addi- tion, microaesthetes are present between granules too. Maximum length of granules: $c a 45-60 \mu \mathrm{m}$ in head valve, ca $65-80 \mu \mathrm{m}$ in intermediate valves.

Articulamentum with wide and triangular apophyses in intermediate valves, slit formula ?/1/?, slit deep.

Remarks. - The paralectotype of Tonicia pannonica (Szôts, 1953, pl. 1, figs 1, 2) is here excluded from that species and re-assigned to the genus Lepidochitona, based on valve shape and ornamentation (Fig. 2C, F). It fits well with the present species and likely represents a second intermediate valve.

In spite of the scarcity of the available material, this species is well characterized by its coarser and dense granules, which tend to coalesce, the presence of radial ridges in the head valve, and a diagonal fold in lateral areas. It differs from the L. gantensis sp. nov. by the presence of a distinct fold separating the central and lateral areas. Three other Lepidochitona species from the European Eocene show a similar morphology (Dell'Angelo et al. 2011, Appendix 2): L. bernayi (Cossmann, 1888), L. defrancei (de Rochebrune, 1883), and L. grinionensis (Lamarck, 1802). The main characters of these species are presented in Table 1, based on the descriptions of Cossmann (1888) for specimens from the Paris Basin.

Material of Lepidochitona grinionensis (MNHN J02645, an intermediate valve from Ferme de l'Orme, illustrated in Cossmann \& Pissarro 1907) and L. defrancei (MNHN J02646, three valves from Chaussy, illustrated in Cossmann \& Pissarro 1907) show characters that substantially agree with those deduced from historical descriptions 
and reported in Table 1. The intermediate valves of Lepidochitona szoetsi $\mathrm{sp}$. nov. are superficially similar to L. defrancei. The strong diagonal fold is very similarly developed, as is the ornamentation, but the overall shape of valves of $L$. szoetsi sp. nov. is different, more elongated, and the head valve of $L$. defrance $i$ is also different in shape, with no traces of radial ribs. Unfortunately, we were neither able to trace the types of $L$. defrancei, nor to locate topotypic material (the MNHN specimens come from different localities and it is not clear if they are really conspecific with the type material of de Rochebrune). Notwithstanding the scarcity of the material available, we describe Lepidochitona szoetsi sp. nov. as a new species. It must be pointed out, however, that the Paris Basin chitons are poorly known and in need of re-description based on SEM-documentation of the type-material. When more data becomes available, it will be possible to better define the relations between Lepidochitona szoetsi sp. nov. and L. defrancei.

Occurrence. - Lepidochitona szoetsi sp. nov. is known only from the Middle Eocene of Gánt (Hungary).

\section{Discussion}

Tonicia pannonica from the Eocene of Gánt was described by Szôts (1953) on the basis of two isolated valves, deposited at the HGGI. New samples were collected near the type locality and were checked specifically for chiton valves. Nearly 200 specimens could be recovered. Although most of them are fragmented, four species could be recognized based on valve shapes and tegmentum ornamentation.

Re-examination of the type material of Tonicia pannonica indicates that the two syntypes of Szóts (1953) belong to two different species. One syntype (the tail valve) does indeed belong to the genus Tonicia but the other one is a Lepidochitona. In agreement with the recommendations of The Code (ICZN 1999, Recommendation 74A), the tail valve is here selected as the lectotype for Tonicia pannonica, in order to stabilize nomenclature by preserving the attribution of pannonica to Tonicia. The paralectotype, an intermediate valve, is excluded from T. pannonica here and attributed to Lepidochitona szoetsi sp. nov. on base of its ornamentation.

Comparison with other species of Tonicia and Lepidochitona is generally hampered by the poor or incomplete descriptions for many nominal taxa included in these two genera. Particularly, SEM-documentation of their ornamentation is often lacking and original descriptions are usually presented in general terms. For the Paris Basin chiton fauna no modern revision is available and often repository of the type-material is unknown, making it even more difficult to compare taxa from that region to new finds from elsewhere. As pointed out by Puchalski et al. (2008) and exemplified by the present study sampling specifically targeted at the recovery of polyplacophoran valves often results in an increase in local and sometimes global chiton biodiversity since polyplacophoran valves (especially of small species) can easily be overlooked or confused with broken bivalve shells.

\section{Conclusions}

Revision of Szőts's (1953) type material of Tonicia pannonica from the Eocene of Gánt revealed the presence of a second species among the syntypes and necessitated designation of a lectotype. New material collected near the type locality considerably extended our knowledge of the Hungarian Eocene chiton fauna, as well as the general knowledge of Palaeogene polyplacophorans and resulted in the identification of three Lepidochitona taxa in addition to Tonicia pannonica: Lepidochitona gantensis sp. nov., L. szoetsi sp. nov., and L. viciani sp. nov.

\section{Acknowledgements}

The authors wish to thank Zoltán Vicián (Budapest, Hungary) for providing a large amount of sediment from Gánt, Klára Palotás (Budapest, Hungary) for access to the type material of Szôts and Helmut Krock (Lüneburg, Germany) for additional chiton specimens (about a third of the valves described in this work). The visit of B.D. to the NHMW was supported by a grant from the European Commission's (FP 7) Integrated Infrastructure Initiative programme SYNTHESYS. A.D. was supported by Hungarian Scientific Research Foundation (OTKA K 77451 and K 112708). The critical reviews of Julia D. Sigwart (Belfast, United Kingdom) and Lesley Cherns (Cardiff, United Kingdom) are gratefully acknowledged.

\section{References}

Bignot, G., Blondeau, A., Guernet, C., Perreau, M., Poignant, A., Renard, M., Riveline, J., Gruas, C., Dudich, E., Kázmér, M. \& Kopeк, G. 1985. Age and characteristics of the Eocene transgression at Gánt (Vértes Mountains, Transdanubia, Hungary). Acta Geologica Hungarica 28, 29-48.

BoetTGER, O. 1869. Beitrag zur palaeontologischen und geologischen Kenntniss der Tertiarformation in Hessen. 33 pp. Offenbach am Main.

Budai, T., Császár, G., Csillag, G., Fodor, L., Gál, N., Kercsmár, Z., Kordos, L., PÁlfalvi, S. \& Selmeczi, I. 2008. Magyarázó a Vértes hegység földtani térképéhez (1:50000). [Explanatory Book to the Geological Map of the Vértes Hills (1:50000)]. 368 pp. Geological Institute of Hungary, Budapest.

Cabrera, M.I.L. \& Olivero, E.B. 2011. An Eocene articulated polyplacophora (Mollusca) from the La Meseta Formation, 
Antarctica and the stratigraphy of the fossil-bearing strata. Journal of Paleontology 85, 970-976. DOI 10.1666/10-161.1

Cossmann, M. 1888. Catalogue illustré des coquilles fossiles de l'Eocène des environs de Paris. Troisième fascicule. Annales de la Société Royale Malacologique de Belgique 23, 3-324.

Cossmann, M. \& Pissarro, G. 1902. Faune éocènique du Cotentin. 3ème article. Bulletin de la Société Géologique de Normandie 21(1901), 27-181.

Cossmann, M. \& Pissarro, G. 1905. Faune éocènique du Cotentin. 6ème article. Bulletin de la Société Géologique de Normandie 24, 16-86.

Cossmann, M. \& Pissarro, G. 1907. Iconographie complète des coquilles fossiles de l'Éocène des environs de Paris, Tome 2, pars. 1-9 pls. Hermann, Paris.

Dell'Angelo, B., Bonfitto, A. \& Taviani, M. 2011. Chitons (Polyplacophora) from Paleogene Strata in Western Washington State, U.S.A. Journal of Paleontology 85, 936-954. DOI $10.1666 / 10-114.1$

Dell'Angelo, B., Quaggiotto, E. \& Sosso, M. 2012. First record of a chiton (Mollusca: Polyplacophora) from the Eocene of Italy. Studi e Ricerche - Associazione Amici del Museo Museo Civico "G. Zannato” Montecchio Maggiore (Vicenza) 19, 27-29.

HaLuPKA, G. 1999. A gánti középső-eocén üledékek paleoökológiai helyzetéról, foraminiferák tanulmányozása nyomán. [Contribution to the paleoecology of Middle Eocene Sediments at Gánt (Vértes Hills, Transdanubia, Hungary) on the basis of Foraminifera Studies]. Földtani Közlöny 129, 23-39.

ICZN (ed.) 1999. International Code of Zoological Nomenclature. Fourth Edition. xxix +306 pp. International Trust for Zoological Nomenclature, London.

JANSSEN, R. 1978. Revision der Polyplacophora des Oligozäns in Mitteleuropa. Archiv für Molluskenkunde 108, 215-235.

KaAs, P., VAn Belle, R.A. \& Strack, H.L. 2006. Monograph of Living Chitons (Mollusca: Polyplacophora). Volume 6. Suborder Ischnochitonina (concluded): Schizochitonidae; Chitonidae. Additions to Volumes 1-5. 463 pp. Brill, Leiden Boston.

KeCSKemÉTI-KöRmEndy, A. 1990. A Nagyegyháza - Csordakút Mányi-medence eocén Mollusca faunája [La faune de mollusques Éocènes du Bassin Nagyegyháza-Csordakút-Mány]. Annales de l'Institut Geologique de Hongrie 71, 1-269.

Kollányi, K., Bernhardt, B., Báldi-Beke, M. \& Lantos, M. 2003. Dunántúli eocén fúrások integrált sztratigráfiai vizsgálata. [Integrated stratigraphic examination of the Eocene boreholes in Transdanubia]. Földtani Közlöny 133, 69-90.

LAmarcK, J.-B. 1802. Mollusques testacées dont on trouve les dépouilles fossiles dans les environs de Paris. Annales $d u$ Muséum National d'Histoire Naturelle 1, 308-312.

Le Renard, J. \& Gain, O. 2012. Les fossiles de l'Éocène moyen du Cotentin (Manche, France). II. - Définition de la biozone des faluns de Hautteville-Bocage (Éocène moyen). Cossmanniana, Hors-Série 5, 27-170.

MaKarenKo, D.E. 1969. Mail shells (Chitons) of the Paleocene in the Ukraine. Geologichny zhurnal 1969, 24-30. [in Russian]

MıнÁLy, S. 1975. Paleoökológiai megfigyelések a gánti középsô-eocénból. [Paleoecological observations in the Middle Eocene of Gánt, Hungary]. Földtani Közlöny 105, $75-81$.

MinÁLy, S. \& VincZe, P. 1984. Újabb paleoökológiai megfigyelések a gánti középsőeocénből. [New paleoecological remarks concerning the Middle Eocene beds of the Bagoly-hegy at Gánt, Transdanubia, Hungary]. Földtani Közlöny 114, 263-283.

Monostori, M. 1977. Ostracode fauna from the Eocene of Gánt (Transdanubian Central Mountains, Hungary). Annales Universitatis Scientarum Budapestinensis de Rolando Eötvös nominatae, Sectio Geologica 19, 75-129.

Nolf, D. \& Reichenbacher, B. 1999. Fisch-Otolithen aus brackischen Faziesräumen aus dem Mittel-Eozän von Norditalien und Ungarn. Bulletin de l'Institut royal des sciences naturelles de Belgique, Sciences de la terre 69, 187-196.

Puchalski, S.S., Eernisse, D.J. \& Johnson, C.C. 2008. The effect of sampling bias on the fossil record of chitons (Mollusca, Polyplacophora). American Malacological Bulletin 25, 87-95. DOI 10.4003/0740-2783-25.1.87

Rochebrune, A.T. DE 1883. Monographie des espèces fossiles appartenant à la classe des Polyplaxiphores. Annales des Sciences Géologiques 14, 1-74.

RolLE, F. 1862. Uber einige neue oder wenig gekannte Mollusken Arten aus Tertiär-Ablagerungen. Sitzungsberichte der Kaiserlichen Akademie der Wissenschaften, mathematischnaturwissenschaftliche Classe, Abtheilung I 44, 205-224.

Sigwart, J., CArey, N. \& OrR, P.J. 2014. How subtle are the biases that shape the fidelity of the fossil record? A test using marine molluscs. Palaeogeography, Palaeoclimatology, Palaeoecology 403(1), 119-127.

DOI 10.1016/j.palaeo.2014.02.025

Sirenko, B. 2006. New Outlook on the System of Chitons (Mollusca: Polyplacophora). Venus 65, 27-49.

STRAuSz, L. 1962. A gánti eocén fauna ökológiai viszonyai. (Über die paläoökologischen Verhältnisse der Eozänfauna von Gánt). Földtani Közlöny 92, 308-318.

Strausz, L. 1974. Neszmélyi eocén puhatestúek. [Die Eozänmollusken von Neszmély (Ungarn)]. Geologica Hungarica, Series Palaeontologica 38, 1-160.

SzŐTs, E. 1953. Magyarország eocén puhatestúi. I. Gántkörnyéki eocén puhatestúek. [Mollusques Éocènes de la Hongrie. I. Les mollusques Éocènes des environs de Gánt]. Geologica Hungarica, Series Palaeontologica 22, 1-270.

Van Belle, R.A. 1981. Catalogue of Fossil Chitons. 84 pp. Backhuys, Rotterdam. 